\title{
The effect of the absence of rumen ciliate protozoa on growing lambs fed on a roughage-concentrate diet
}

\author{
By J. MARGARET EADIE AND J. C. GILL \\ Rowett Research Institute, Bucksburn, Aberdeen $A B 2{ }_{9} S B$ \\ (Received 15 Fune 1970 - Accepted I5 April 1971)
}

\begin{abstract}
I. Lambs were removed from their dams at $2 \mathrm{~d}$ of age, and at 5 weeks of age eight of one group were inoculated with a mixed rumen ciliate population and seven in a second group were maintained ciliate-free throughout the 6I weeks of the experiment. Performance of the groups was compared when given a $2:$ I roughage:concentrate diet as a set ration and with ad lib. roughage.

2. Mixed ciliate populations developed in all faunated lambs and average-sized populations were maintained. Large numbers of flagellate protozoa developed in the ciliate-free animals after flagellates had been introduced into the building with the ciliate inoculum.

3. Higher numbers of rumen bacteria were found in the ciliate-free group.

4. Only between the 14 th and 2 I st weeks was there a significant difference between groups in weight gain and this was in favour of the faunated group. The only significant difference in body measurements was a greater girth in the ciliate-free lambs.

5. Only minor differences were found between the groups in calorimetric trials, digestibility and nitrogen balances. There were no differences between groups in concentration of total protein $\mathrm{N}$ and soluble sugar in the rumen. The ammonia concentration was significantly higher in the faunated group.

6. The concentrations of total rumen volatile fatty acids (VFA) were higher in the faunated group. Differences, between groups, in proportions of VFA were attributed to the activity of the rumen bacteria rather than the ciliates per se.

7. No differences between groups were found in the concentrations of blood sugar and haemoglobin.

8. It was concluded that the changes due to the presence of rumen ciliates were not great enough to be reflected in animal performance under the conditions of this experiment.
\end{abstract}

The fact that the absence of rumen ciliate protozoa has no serious deleterious effect upon ruminants has been known for a considerable time (Becker \& Everett, 1930; Becker, Schulz \& Emmerson, 1930; Pounden \& Hibbs, 1950). There have, however, been a number of conflicting reports as to the positive value of the presence of rumen ciliates, and not until the work of Abou Akkada \& El Shazly $(1964,1965)$ and Christiansen, Kawashima $\&$ Burroughs (1965) was there any report of improvement in animal performance which could be attributed to their presence. In view of the observations made by these workers and later reports by Luther, Trenkle \& Burroughs (1966) and Klopfenstein, Purser \& Tyznik (1966), we have carried out a more detailed comparison of ciliate-free and faunated sheep than was previously felt to be justified (Eadie, 1962). Lambs in which ciliates were established by rumen inoculation were compared with those in which a ciliate population had been prevented from developing by isolating them from other ruminants from $2 \mathrm{~d}$ of age. This work has already been reported in part by Chalmers, Davidson, Eadie \& Gill (1968). 


\section{EXPERIMENTAL}

\section{Animals and housing}

North Country Cheviot lambs were removed from their dams at $2 \mathrm{~d}$ of age, fed on milk by bottle and reared in a group indoors. At 3 weeks of age, eight male and eight female animals were paired according to age, sex and weight; one member of each pair was allocated to the ciliate-free group and the other to the group which was to be faunated. Eight faunated lambs and seven ciliate-free lambs were successfully reared and, though the pairs of lambs were no longer complete, group comparison could be continued.

All lambs on experiment had been born within a period of $16 \mathrm{~d}$ and the average age for each of the two groups differed by less than I d. Sample times were so arranged that at each measurement the experimental animals did not differ in age by more than $4 \mathrm{~d}$. Throughout this report 'weeks' will refer to the age of the animals.

The two groups of animals were physically isolated from each other in virtually identical ends of the building in which they were reared. The mean daily ambient temperature rarely differed by more than $I^{\circ}$. There were no other ruminants in this building. The lambs were bedded on sawdust in individual pens. Contact between the neighbouring animals of one group was possible and aerial contact between the two groups was not completely eliminated. However, great care was taken to prevent direct transfer of rumen material from one group to the other. All the lambs remained ciliate-free until inoculation at 5 weeks of age.

All lambs were docked and the males castrated at 6 weeks. The animals remained healthy except for a few cases of bloat in the early stages. The lambs were weighed at fortnightly intervals and measurements of body length, height and girth were taken less frequently. At 60 weeks the lambs were shorn and fleece weights were recorded.

\section{Feeding}

The major changes in the feeding regimen are given in Table $\mathrm{I}$. The lambs were fed on warmed cow's milk by bottle, the amount being gradually increased from I 42 to $568 \mathrm{ml}$ per feed. A separate feeding bottle and teat were provided for each lamb and these were used for the same animal throughout the period of milk-feeding. Bottles and teats were thoroughly washed between each feed. After large milk clots had been found in the abomasum of the lamb which died from bloat at 9 weeks, sodium citrate was added to the milk at the rate of $0.5 \mathrm{~g} / 568 \mathrm{ml}$.

Each animal was weaned by reducing the milk intake over $4^{8 \mathrm{~h}}$. The concentrate ration used throughout was made up of 8 parts maize, 2 parts oats, 2 parts bran, I part linseed cake, I part white-fish meal and a vitamin supplement. A multivitamin injection was given, and a mineral lick was made available to all animals at $3^{6}$ weeks and $5 \mathrm{~g}$ of salt were added to one concentrate feed each day. The roughage portion of the ration was changed from dried grass to hay at 30 weeks, but because all animals failed to eat the hay, which was of poor quality, it was necessary to revert to dried grass. In some instances full appetite was not regained until almost 2 weeks after the return 
to dried grass. From 39 weeks onwards there was no alteration in food intake except that while energy-metabolism experiments were in progress daily intake was reduced to $600 \mathrm{~g}$ dried grass and $300 \mathrm{~g}$ concentrates.

The daily feeding times up to 15 weeks were 09.00 hours, 14.00 hours and 19.00 hours, and from 15 to 24 weeks they were 08.30 hours, II.3O hours and 16.30 hours. For the twice-daily feeding schedules, feeding times were 08.30 hours and 16.30 hours.

Table I. Ration offered daily to ciliate-free and faunated lambs

$\begin{array}{cccccc}\text { Age (weeks) } & \begin{array}{c}\text { Milk } \\ (\mathrm{ml} / \mathrm{d})\end{array} & \begin{array}{c}\text { Dried grass } \\ (\mathrm{g})\end{array} & \begin{array}{c}\text { Hay } \\ (\mathrm{g})\end{array} & \begin{array}{c}\text { Concen- } \\ \text { trates }(\mathrm{g})\end{array} & \begin{array}{c}\text { No. of equal } \\ \text { feeds }\end{array} \\ 0-3 & 425-1700 & - & - & - & 3 \\ 4-13 & 1700 & \text { ad lib. } & - & - & 3 \\ 14-23 & - & \text { ad lib. } & - & 300 & 3 \\ 24-29 & - & \text { ad lib. } & - & 300 & 2 \\ 30-31 & - & 300 & 300 & 300 & 2 \\ 32-33 & - & - & 600 & 300 & 2 \\ 34-39 & - & 600 & - & 300 & 2 \\ 40-61 & - & 700 & - & 350 & 2\end{array}$

Rumen sampling method and rumen ciliate inocula

All rumen samples were taken by stomach-tube (Eadie, 1962).

The first inoculum of mixed ciliates was given at 5 weeks, and similar inocula were given at 6 weeks and ro weeks. An extra inoculum was given to one of the older animals at Ir weeks after a period of poor food consumption. The method of inoculation used was described by Eadie (1962).

The inoculum for each lamb was concentrated from $125 \mathrm{ml}$ of mixed rumen fluid made up of equal volumes of rumen fluid from two adult rumen-cannulated sheep in which similar populations were established. Twenty-five $\mathrm{ml}$ of this concentrated material was given to each animal, $15 \mathrm{ml}$ by stomach-tube and $10 \mathrm{ml}$ direct into the mouth. The organisms present in all the inocula were Polyplastron multivesiculatum (Dogiel \& Fedorowa), Ophryoscolex tricoronatus (Dogiel), Diploplastron affine (Dogiel \& Fedorowa), Isotricha prostoma Stein, Isotricha intestinalis Stein, Dasytricha ruminantium Schuberg and species of the genus Entodinium including E. bursa Stein. Flagellate protozoa were also present in the inocula. Microscopic examination confirmed that the inocula used were similar in activity and proportions although they were prepared on different days.

Within I week of the first inoculation a mixed rumen-ciliate population had developed in all the inoculated lambs and only Ophryoscolex did not develop. Further inocula containing Ophryoscolex were given at $20,3^{\mathrm{I}}$ and $4 \mathrm{I}$ weeks. These inocula were prepared from the rumen fluid of an animal in which Ophryoscolex and Entodinium spp. were maintained as a limited population (Eadie, 1967 ). Three inocula were given to each of the faunated lambs regardless of whether Ophryoscolex had become established from the previous inoculum. 


\section{Microbial examination}

Wet preparations from the rumen fluid of both groups of lambs were examined at regular intervals. Samples were preserved in an equal volume of $10 \%$ formalin and used for later comparisons and for ciliate and bacterial counts.

At 29 weeks and 43 weeks a number of ciliate counts were made using the method previously described by Eadie, Hyldgaard-Jensen, Mann, Reid \& Whitelaw (1970). On the set ration and during the ad lib. feeding period a series of total bacterial counts was made using a Coulter counter (Hobson, Mann \& Summers, I966). Total viable bacterial counts on the starch medium described by Kurihara, Eadie, Hobson \& Mann (1968) were made on samples from a selected number of animals at 43 weeks and 59 weeks. The proportions of certain morphological forms of bacteria in cultures from the two groups were assessed by the examination of a number of colonies randomly chosen from the $10^{6}$ dilution cultures made at the 43 rd week.

Faecal samples were examined at $3^{\mathrm{I}}$ weeks for helminth eggs and coccidia.

\section{Analytical methods}

Volatile fatty acids $(V F A)$. The concentration of VFA in the rumen fluid at 26 weeks was determined by the method of Storry \& Millard (1965). At 59 weeks the proportions of VFA were determined as described by Fell, Kay, Whitelaw \& Boyne (I968).

Rumen fuid ammonia and nitrogen determinations. Total rumen ammonia was determined by the Conway method, as described by Chalmers, Cuthbertson \& Synge (1954). The soluble $\mathrm{N}$ components of the rumen material were analysed in clarified rumen fluid prepared by centrifugation at $62000 \mathrm{~g}$ for $20 \mathrm{~min}$. To obtain a large enough volume of fluid, pooled $40 \mathrm{ml}$ samples from several animals were used, and total $\mathrm{N}$ and rumen ammonia concentrations were also determined in these samples.

Following the main experiment two ciliate-free and two faunated animals were used to obtain further rumen $\mathrm{N}$ and ammonia values. The two ciliate-free animals were then inoculated with rumen ciliates and the determinations were repeated when ciliate populations had become established.

Soluble sugars in rumen fluid. Values for soluble sugars in clarified fluid from the larger rumen samples were determined by the phenol-sulphuric acid method of Dubois, Gilles, Hamilton, Rebers \& Smith (1956) using fructose as standard.

Blood analyses. Blood samples were taken at the 27 th and the 36 th week. Haemoglobin was estimated spectrophotometrically as oxyhaemoglobin, the concentration being calculated from the values given by Heilmeyer (1943). Blood glucose was estimated by the glucose oxidase method of Hugget \& Nixon (1957).

\section{Energy metabolism}

Energy-metabolism experiments were carried out on four pairs of animals in the period between 46 and 58 weeks. For each trial a pair of animals from the same group was used and these were removed from the main experimental building for 18-2I $\mathrm{d}$. Because of the convenience of using male animals one of the ciliate-free lambs was used twice. 
The respiratory exchange of the sheep was measured using the closed-circuit respiration apparatus briefly described by Wainman \& Blaxter (1969). Heat production was computed using the factors of Brouwer (1965). Digestibility values were also determined over excreta collection periods of 9-12 d.

To avoid the possibility of contamination of the ciliate-free animals or alterations in the flora of the faunated ones, control and ciliate-free lambs were never in the building housing the respiration apparatus at the same time.

\section{Digestibility and $N$ balance trials}

At around 62 weeks the four animals kept for further studies of rumen fluid $\mathrm{N}$ (p. ${ }^{5}{ }^{8}$ ) were placed in metabolism cages, and digestibility and $\mathrm{N}$ balance values were determined by the method described by Chalmers et al. (1954). The ciliate-free animals were housed in a different room from the faunated lambs but apart from this the treatments were identical. The usual precautions were taken to prevent contamination, and the success of this was confirmed by regular microscopic examination of rumen fluid.

The proximate composition was estimated according to the Association of Official Agricultural Chemists (1960). Gross energy was determined in an adiabatic bomb calorimeter.

\section{RESULTS}

\section{Food consumption and growth}

There was no significant difference in live weight between the groups before inoculation with rumen ciliates.

Table 2. Food consumption and live-weight gains of ciliate-free and faunated lambs

\begin{tabular}{|c|c|c|c|c|c|c|}
\hline $\begin{array}{c}\text { Age } \\
\text { (weeks) }\end{array}$ & Diet & & $\begin{array}{r}\text { Ciliat } \\
\text { free }\end{array}$ & Faunated & $\begin{array}{l}\text { Difference with } \\
\text { its sE (ciliate- } \\
\text { free - faunated) }\end{array}$ & Significance \\
\hline \multicolumn{7}{|c|}{ Mean food consumption } \\
\hline $7^{-13}$ & Milk & (1/week) & I I $\cdot 8$ & I I 99 & $-0.1 \pm 0.09$ & NS \\
\hline $7-13$ & Dried grass ad lib. & \multirow{6}{*}{ (kg/week) } & $\mathbf{I} \cdot 9$ & $\mathrm{I} \cdot 9$ & $0.0 \pm 0.22$ & \multirow{5}{*}{$\begin{array}{c}\text { NS } \\
P<0.05 \\
\text { NS } \\
\text { NS } \\
\text { NS }\end{array}$} \\
\hline $14-21$ & Dried grass ad lib. & & $5 \cdot 9$ & $6 \cdot 3$ & $-0.4 \pm 0.19$ & \\
\hline $22-29$ & Dried grass ad lib. & & $8 \cdot 2$ & $8 \cdot 5$ & $-0.3 \pm 0.33$ & \\
\hline $14-29$ & Concentrates & & $2 \cdot 1$ & $2 \cdot I$ & 0.0 & \\
\hline $30-35$ & $\begin{array}{l}\text { Dried grass or hay }+ \\
\text { concentrates restricted }\end{array}$ & & $5 \cdot 9$ & $5 \cdot 7$ & $+0.2 \pm 0.05$ & \\
\hline $3^{6-59}$ & $\begin{array}{l}\text { Dried grass }+ \\
\text { concentrates restricted }\end{array}$ & & $7 \cdot 1$ & $7 \cdot 0$ & $+0.1 \pm 0.05$ & NS \\
\hline \multicolumn{7}{|c|}{ Mean live-weight gain (kg/week) } \\
\hline $7-13$ & & & $1 \cdot 62$ & $1 \cdot 55$ & $+0.07 \pm 0.18$ & \multirow{5}{*}{$\begin{array}{c}\text { NS } \\
P<0.01 \\
\text { NS } \\
\text { NS } \\
\text { NS }\end{array}$} \\
\hline $14-21$ & & & $I \cdot 59$ & $x \cdot 92$ & $-0.33 \pm 0.10$ & \\
\hline $22-29$ & & & $\mathrm{I} \cdot \mathrm{Or}$ & 0.99 & $+0.02 \pm 0.11$ & \\
\hline $30-35$ & & & -0.43 & $-0.6 \mathrm{I}$ & $+0.18 \pm 0.16$ & \\
\hline $36-59$ & & & $0.5^{8}$ & 0.50 & $+0.08 \pm 0.05$ & \\
\hline
\end{tabular}

There was no significant difference in mean food consumption between the groups over the periods of the experiment which corresponded with changes in ration, nor was there any difference in rate of weight gain over these periods. However, as shown 
in Table 2, during the period $\mathrm{I} 4$ to $2 \mathrm{I}$ weeks the faunated animals ate significantly more dried grass and showed a significantly greater rate of live-weight gain. Values for individual lambs, when examined on the basis of within-treatment comparisons, showed no statistically significant relationship between weight gain and dried grass intake over the period from 14 to $2 \mathrm{I}$ weeks so that, at that stage, the effect may have been partly due to the rumen microbial population.

At the period of reduced intake from 30 to 35 weeks the ciliate-free animals ate more. The animals with the lowest and highest food intakes were equally distributed between the groups.

When the animals were shorn at about 60 weeks there was no significant difference in fleece weight, the mean weight for the faunated group being $4.0 \mathrm{~kg}$ and for the ciliate-free group $4^{\cdot} \mathrm{I} \mathrm{kg}$.

There was no significant difference between the two groups in body length or height, but girth measured after shearing was significantly greater in the ciliate-free group $(P=0.01)$ (Chalmers et al. 1968).

\section{Microbial populations}

Development of ciliates. Two organisms from the original inocula did not develop in all of the lambs. Shortly after inoculation Diploplastron was seen in all eight faunated lambs but in two of the animals it died out at 28 weeks. Ophryoscolex was not seen in any of the lambs before the limited population was used as an inoculum. It then developed in three of the lambs but remained in only two of these until the end of the experiment.

Except for these differences in the minor components of the populations, the ciliate species and proportions were rather similar in all eight animals and there were few marked fluctuations. At 29 weeks counts on rumen samples from three sheep gave values of $7-9 \times 10^{5} / \mathrm{ml}$. During the period of restricted ration at 43 weeks, counts from five animals ranged from 6 to $12 \times 10^{5} / \mathrm{ml}$. These figures confirm the microscopic observations. The variation between animals was not great even when 'totalunit' values, a measure of total rumen ciliate volume, were considered (Eadie $e t$ al. 1970).

Establishment of flagellate protozoa. Flagellate protozoa were not seen in samples from either group of lambs until after the first inoculum was given to the faunated animals. After inoculation they developed in all lambs of the faunated group. They were first seen in the ciliate-free lambs in samples taken from 7 to $25 \mathrm{~d}$ after the first inoculum was given to the other group. The ciliate-free lambs were from $4 \mathrm{I}$ to $57 \mathrm{~d}$ old at this time.

Gram-film examinations of the rumen bacteria. The lambs of each group showed remarkably similar Gram-film pictures throughout the experiment. There were, however, differences between the groups. The smears from both groups showed the background of Gram-negative cocci typical of the roughage-concentrate diet. Among the smaller bacteria the most notable difference between the groups was the greater number of typical rod forms of Bacteroides in the faunated animals and the greater number of Streptococcus bovis in the ciliate-free animals. As in previous studies 
(Eadie, 1962), large Gram-positive to Gram-variable rods were present in all ciliatefree animals at some stage in the experiment. Only a very occasional one was seen in smears from the faunated lambs. The slender Gram-positive to variable rods, noted by Eadie ( 1962 ) to be associated with the presence of ciliates, were seen in relatively large numbers in all faunated animals, although the time of appearance varied and did not coincide with the first development of ciliates. These rods were never seen in the ciliate-free animals. The development of populations of selenomonads, Quin's ovals and Oscillospira followed a fairly predictable course in the ciliate-free lambs (Eadie, r962) with small selenomonads developing first and Oscillospira last. In the faunated animals the order of appearance was not so clear, since all three were present in the inoculum and developed together. There was a markedly larger number of Quin's

Table 3. Mean total counts of rumen bacteria in ciliate-free and faunated lambs

\begin{tabular}{|c|c|c|c|c|}
\hline \multirow{3}{*}{$\begin{array}{c}\text { Age (weeks) } \\
29\end{array}$} & \multicolumn{2}{|c|}{ Mean values $\left(\times 10^{-9} / \mathrm{ml}\right)$} & \multirow{2}{*}{$\begin{array}{c}\text { Difference with its SE } \\
\text { (ciliate-free - } \\
\text { faunated) }\end{array}$} & \multirow{3}{*}{$\begin{array}{c}\text { Significance } \\
\text { NS }\end{array}$} \\
\hline & Ciliate-free & Faunated & & \\
\hline & I0. 5 & 6.9 & $3 \cdot 6 \pm 1 \cdot 7$ & \\
\hline 43 & $17 \cdot 1$ & $7 \cdot 5$ & $9 \cdot 6 \pm 1 \cdot 2$ & $P=0.001$ \\
\hline 59 & 10.5 & $6 \cdot 7$ & $3 \cdot 8 \pm 1 \cdot 7$ & $P=0.05$ \\
\hline
\end{tabular}

ovals in the faunated animals and a markedly larger number of Oscillospira in the ciliate-free animals. The average width of the Oscillospira in the ciliate-free animals was about $60 \%$ of the width of those in the faunated animals. The large oval organism 'Eadie's oval' developed in really large numbers for temporary periods in seven of the eight ciliate-free lambs. The eighth animal showed relatively few of these organisms. These organisms were rarely seen in the faunated animals and then only an odd cell was found after a prolonged search.

Types of bacteria from culture. An examination of the properties of different morphological forms of rumen bacteria found in culture showed, as the most obvious differences, a greater proportion of Bacteroides-like rods and selenomonads in the faunated animals and a greater proportion of bacteria morphologically similar to $S$. bovis in the ciliate-free group. This agreed with previous findings (Kurihara et al. I968).

Bacterial numbers. Table 3 lists the mean values for total bacterial counts at 29 weeks, during the period when grass was being given to appetite and on two occasions during the period of set-ration. In agreement with previous findings, the ciliate-free group had, in all instances, higher mean bacterial counts, although the difference did not quite reach significance at 29 weeks. The mean value for total bacterial count in the four ciliate-free animals examined at 43 weeks was $15^{\circ} .9 \times 10^{9}$ and that for the four faunated animals was $7.9 \times 10^{9}$. The values for viable count ranged from 6.3 to $8.5 \times 10^{8}$ with a mean of $7.6 \times 10^{8}$ in the ciliate-free animals and from 3.8 to 6.8 with a mean of $5.3 \times 10^{8}$ in the faunated animals. Thus the difference between the mean viable counts for each group was not as great as the difference between the total bacterial counts and there was therefore a higher percentage of viable organisms in the faunated animals. Similar findings were reported for the two animals examined by 
Kurihara et al. (1968). The viable percentages in the present work were reasonably high for roughage-concentrate-fed animals, the mean values being 4.8 and $6.7 \%$ for the ciliate-free and faunated animals respectively. These percentages are much lower than those obtained in cattle fed on a restricted barley diet (Eadie et al. 1970)

Parasites. Coccidia and helminth eggs were seen in faeces from a few animals in each group but the numbers were low.

\section{Rumen VFA}

Table 4 shows that at 26 weeks, during the period of $a d l i b$. feeding, there was a significantly higher total rumen VFA in the faunated animals both before feeding and at 2 and $5.5 \mathrm{~h}$ after feeding. At 59 weeks on the set ration the faunated animals again showed a higher value but the difference did not quite reach significance because of the variability. As would be expected, the rumen $\mathrm{pH}$ tended to be lower in the faunated animals though the difference was slight and all values were well above $6 \cdot 0$.

Table 4. Total concentrations and molar proportions of volatile fatty acids in rumen fluid from ciliate-free and faunated lambs

\begin{tabular}{|c|c|c|c|c|c|c|}
\hline & & & Mean & value & & \\
\hline & $\begin{array}{c}\text { Age } \\
\text { (weeks) }\end{array}$ & Time* (h) & $\begin{array}{l}\text { Ciliate- } \\
\text { free }\end{array}$ & $\underbrace{\mathrm{Di}}_{\text {Faunated }}$ & $\begin{array}{l}\text { ifference with its } \\
\text { E (ciliate-free - } \\
\text { faunated) }\end{array}$ & Significance \\
\hline Total VFA (m-mol/l) & 26 & $\left\{\begin{array}{l}08.15 \\
10.30 \\
14.00\end{array}\right.$ & $\begin{array}{l}51 \cdot 3 \\
67 \cdot 4 \\
51 \cdot 6\end{array}$ & $\begin{array}{l}62 \cdot 6 \\
79 \cdot 9 \\
76 \cdot 6\end{array}$ & $\begin{array}{l}-11 \cdot 3 \pm 3 \cdot 3 \\
-12 \cdot 5 \pm 3 \cdot 9 \\
-25 \cdot 0 \pm 4 \cdot 2\end{array}$ & $\begin{array}{l}P=0.01 \\
P=0.01 \\
P=0.001\end{array}$ \\
\hline Molar proportions VFA (\%) & 59 & 10.30 & $69 \cdot 7$ & $78 \cdot 6$ & $-8 \cdot 9 \pm 5 \cdot 7$ & NS \\
\hline Acetic & 26 & $\left\{\begin{array}{l}08.15 \\
10.30 \\
14.00\end{array}\right.$ & $\begin{array}{l}80 \cdot 0 \\
75 \cdot 4 \\
76 \cdot 6\end{array}$ & $\begin{array}{l}73 \cdot I \\
68 \cdot 5 \\
7 \mathrm{I} \cdot 4\end{array}$ & $\begin{array}{l}+6.9 \pm 3.2 \\
+6.9 \pm 2.0 \\
+5.2 \pm 1.7\end{array}$ & $\begin{array}{l}P=0.05 \\
P=0.01 \\
P=0.01\end{array}$ \\
\hline & 59 & 10.30 & $64 \cdot 7$ & $65 \cdot 7$ & $-1 \cdot 0 \pm I \cdot 9$ & NS \\
\hline Propionic & 26 & $\left\{\begin{array}{l}08.15 \\
10.30 \\
14.00\end{array}\right.$ & $\begin{array}{l}14.7 \\
15.9 \\
13.3\end{array}$ & $\begin{array}{l}18.6 \\
21.8 \\
19 \cdot 4\end{array}$ & $\begin{array}{l}-3 \cdot 9 \pm \mathrm{I} \cdot 9 \\
-5 \cdot 9 \pm \mathrm{I} \cdot 8 \\
-6 \cdot 1 \pm \mathrm{I} \cdot 2\end{array}$ & $\begin{array}{c}\text { NS } \\
P=0.01 \\
P=0.001\end{array}$ \\
\hline & 59 & 10.30 & $21 \cdot 5$ & $19 \cdot 4$ & $+2 \cdot 1 \pm I \cdot 2$ & NS \\
\hline Butyric & 26 & $\left\{\begin{array}{l}08.15 \\
10.30 \\
14.00\end{array}\right.$ & $\begin{array}{r}5 \cdot 2 \\
8 \cdot 2 \\
10 \cdot 1\end{array}$ & $\begin{array}{l}8 \cdot 0 \\
9 \cdot 5 \\
9 \cdot 5\end{array}$ & $\begin{array}{l}-2 \cdot 8 \pm I \cdot 5 \\
-\quad I \cdot 3 \pm I \cdot 0 \\
+\quad 0 \cdot 6 \pm I^{\prime} 5\end{array}$ & $\begin{array}{l}\text { NS } \\
\text { NS } \\
\text { NS }\end{array}$ \\
\hline & 59 & 10.30 & $9 \cdot 5$ & II' 4 & $-1 \cdot 9 \pm 0 \cdot 7$ & $P=0.05$ \\
\hline
\end{tabular}

NS, not significant.

* Feeding times 08.30 and 16.30 hours.

At 26 weeks the ciliate-free animals showed, after feeding, significantly higher values for acetic acid and lower values for propionic acid (Table 4). There was no significant difference in butyric acid. At 59 weeks the faunated animals had a higher proportion of butyric acid but showed no significant difference in the other acids. There was no evidence that the different methods of analysis of the two sets of samples could have significantly affected the values obtained. 


\section{Rumen ammonia and total $N$ values}

The significantly higher concentrations of rumen ammonia in the faunated animals are clearly demonstrated in Table 5 . Similar differences were seen at 26 and 37 weeks when the larger samples were taken for analysis. In these latter samples no differences could be detected in total rumen fluid $\mathrm{N}$ nor in the total soluble $\mathrm{N}$ and non-protein $\mathrm{N}$ (NPN), when allowance was made for the difference in ammonia $\mathrm{N}$.

Table 6 shows that after a ciliate population was established the rumen ammonia concentrations of two of the original ciliate-free animals altered to reach values similar to those in the faunated controls.

Table 5. Ammonia nitrogen in rumen fluid from ciliate-free and faunated lambs

\begin{tabular}{|c|c|c|c|c|c|}
\hline \multirow{2}{*}{$\begin{array}{c}\text { Age } \\
\text { (weeks) }\end{array}$} & \multirow[b]{2}{*}{ Time* (h) } & \multicolumn{2}{|c|}{ Mean value $(\mathrm{mg} / \mathrm{r} 00 \mathrm{ml})$} & \multirow{2}{*}{$\begin{array}{l}\text { Difference with its } \\
\text { SE (ciliate-free - } \\
\text { faunated) }\end{array}$} & \multirow[b]{2}{*}{ Significance } \\
\hline & & Ciliate-free & Faunated & & \\
\hline 26 & $\left\{\begin{array}{l}08.15 \\
10.30 \\
14.00\end{array}\right.$ & $\begin{array}{l}8 \cdot 4 \\
9 \cdot 6 \\
7 \cdot 8\end{array}$ & $\begin{array}{l}14 \cdot 5 \\
19 \cdot 7 \\
\times 3 \cdot 3\end{array}$ & $\begin{array}{l}-6 \cdot I \pm I \cdot 2 \\
-I 0 \cdot I \pm I \cdot 8 \\
-5 \cdot 5 \pm I \cdot I\end{array}$ & $\begin{array}{l}P=0.001 \\
P=0.001 \\
P=0.001\end{array}$ \\
\hline 37 & 10.30 & $\mathrm{I} 4.4$ & $24 \cdot 6$ & $-10 \cdot 2 \pm 2 \cdot 2$ & $P=0.01$ \\
\hline
\end{tabular}

Table 6. Ammonia nitrogen in rumen fluid from two lambs before and after inoculation with rumen ciliates and from two faunated lambs

\begin{tabular}{|c|c|c|c|c|c|}
\hline \multirow[b]{3}{*}{ Age (weeks) } & \multirow[b]{3}{*}{ Time* (h) } & \multicolumn{4}{|c|}{ Ammonia-N (mg/100 ml) } \\
\hline & & \multicolumn{2}{|c|}{ Ciliate-free } & \multicolumn{2}{|c|}{ Faunated } \\
\hline & & Lamb 40 & Lamb 47 & Lamb 48 & Lamb $5^{\circ}$ \\
\hline c. 26 & $\begin{array}{l}08.15 \\
10.30\end{array}$ & $\begin{array}{l}4.0 \\
5 \cdot 5\end{array}$ & $\begin{array}{r}7 \cdot 1 \\
10 \cdot 4\end{array}$ & $\begin{array}{l}12 \cdot 0 \\
16 \cdot 6\end{array}$ & $\begin{array}{l}18 \cdot 5 \\
21 \cdot 2\end{array}$ \\
\hline c. 60 & $\begin{array}{l}08.15 \\
10.30\end{array}$ & $\begin{array}{r}\text { I 1 .6 } \\
9.9\end{array}$ & $\begin{array}{l}12 \cdot 7 \\
15.9\end{array}$ & $\begin{array}{l}18 \cdot 0 \\
29 \cdot 1\end{array}$ & $\begin{array}{l}21 \cdot 5 \\
25 \cdot 4\end{array}$ \\
\hline c. $66 \dagger$ & $\begin{array}{l}08.15 \\
10.30\end{array}$ & $\begin{array}{l}17.0 \\
19.5\end{array}$ & $\begin{array}{l}23.5 \\
24.0\end{array}$ & - & - \\
\hline c. 76 & $\begin{array}{l}08.15 \\
10.30\end{array}$ & $\begin{array}{l}17.9 \\
20.4\end{array}$ & $\begin{array}{l}I 8 \cdot 3 \\
20 \cdot 5\end{array}$ & - & - \\
\hline
\end{tabular}

Soluble sugars in rumen fluid

There was no significant difference between the groups in the amount of soluble sugar in the rumen fluid, the mean value for samples taken at 27 and 37 weeks being $219 \mathrm{mg} / 100 \mathrm{ml} \mathrm{rumen} \mathrm{fluid} \mathrm{in} \mathrm{the} \mathrm{ciliate-free} \mathrm{and} 199 \mathrm{mg} / 100 \mathrm{ml}$ in the faunated group. We are unable to explain the lower values for reducing sugars obtained in the ciliate-free animals by Abou Akkada \& El Shazly (I964). 


\section{Blood analysis}

Blood sugar and haemoglobin values showed no significant differences between the groups. The mean value for blood sugar was $62.0 \mathrm{mg} / 100 \mathrm{ml}$ in the ciliate-free group and $6 \mathrm{I} \cdot 5$ in the faunated group. The mean values for blood haemoglobin were $12.3 \mathrm{~g} / 100 \mathrm{ml}$ in the ciliate-free and 12.0 in the faunated group.

\section{Digestibility and $N$ balance trial}

There was no significant difference in the values for $\mathrm{N}$ digestibility and $\mathrm{N}$ balance determined for two animals from each group at around 62 weeks. The animals were in positive $\mathrm{N}$ balance, the mean value being $+4.8 \mathrm{~g} / \mathrm{d}$ for the ciliate-free and $+5 . \mathrm{Ig} / \mathrm{d}$ for the faunated animals. The crude-fibre digestibility was higher in the ciliate-free animals in this trial $(P=0.05)$ but was not significantly higher in the trials carried out during the energy-metabolism experiments.

\section{Energy metabolism}

Unfortunately a small difference between the two groups occurred with respect to intake of food. Even so, it was apparent that there was no statistically significant difference between the two groups in terms of faecal loss of energy, but the urine loss of energy was significantly greater in the faunated animals $(P=0.05)$. The methane production of the faunated lambs tended to be higher than that of the ciliate-free lambs but the difference did not quite reach statistical significance $(P=0.055)$. A relatively higher percentage of dietary energy lost as heat by the faunated sheep reflected differences in intake, and so did a marginally lower energy retention. A plot of energy retention against food intake for the two groups did not suggest any difference in energy retention at constant food intake, an observation in agreement with the studies on body-weight gain.

\section{DISCUSSION}

Because of the uniform management and good health of the two groups of lambs there was no external bias in favour of one or other group at any stage in the present work. The microbiology of the rumen of the lambs compared very favourably with that noted during previous studies involving ciliate-free and faunated animals (Eadie, 1962, 1967) and within each group the microbiology seemed remarkably uniform. There is no record of the numbers of rumen ciliates in the faunated animals used by Abou Akkada \& El Shazly $(1964,1965)$ and by Christiansen et al. (1965), who each noted differences in live-weight gain in favour of the faunated animals. However, the rations used in our trial were chosen to be similar to theirs; the counts quoted by Hungate (1966) for rumen ciliates in animals on roughage-concentrate rations were if anything lower than our own. Thus, although the number of animals on experiment was small we feel satisfied that we would have detected any major differences in performance in these particular animals which were caused by the presence or absence of a normal rumen ciliate population, and no such difference was noted. Christiansen 
et al. (1965) were comparing animals similar in size to those in the present experiment. The lambs used by Abou Akkada \& El Shazly (1964) were smaller, their final weights being similar to those of our lambs at 2I weeks. Although we found no differences in live-weight gain or food intake over the full period of the experiment, irrespective of the feeding regimen, we did note differences in favour of the faunated animals between 14 and 21 weeks; that is at a point when our lambs were similar in weight to the Egyptian lambs. The fact that the ciliate-free animals ate more of the poor hay agrees with the original observation of Becker \& Everett (1930), as does the marginally better performance of the ciliate-free animals when poor hay was being given.

Our failure to find any significant differences in $\mathrm{N}$ retention and in the energymetabolism trials is as expected in view of the general performance of the animals. The higher rumen ammonia values in the presence of the ciliates are consistent with the findings of many workers, but on such a high $\mathrm{N}$ intake this difference in ammonia would not affect the $\mathrm{N}$ balance (Chalmers et al. 1968). The small difference in fibre digestibility in favour of the ciliate-free animals was in the opposite direction to that observed by Klopfenstein et al. (1966) in two of their trials.

The only significant difference in body size noted between the groups was that of girth measured after shearing. A pot-bellied appearance has been associated with the ciliate-free state in calves (Pounden \& Hibbs, 1950; Eadie, 1962) and was noted in a ciliate-free concentrate-fed lamb by Becker (1932). The cause of this difference is not known but, in view of the apparent consistency of the observation, it would be interesting to know if a change in rumen volume is involved. Though ciliate-free calves have been noted to have poorer coats than faunated animals there was no obvious difference in wool growth in the lambs.

It is clear from the literature that, although a high concentration of total fatty acid is associated with the presence of ciliates in animals on a roughage-concentrate ration, alterations in the proportions of the acids are not consistent (Christiansen et al. 1965; Luther et al. 1966; Klopfenstein et al. 1966). Our own observations have confirmed this. In contrast, Eadie et al. (I970) found higher concentration of total fatty acids in the absence of, or with low, ciliate populations in steers given restricted amounts of barley and found a high proportion of butyrate to be associated with very large ciliate populations in these animals. The higher concentration of butyrate was directly attributed to the ciliates. With the smaller ciliate populations involved in the present study, it seems more likely that bacterial differences, qualitative, quantitative or both, are the cause of changes in VFA proportions, but it is very doubtful if the small differences in acid proportions which we observed would be attributed to discernible changes in microbial numbers.

As expected, the total bacterial counts for the ciliate-free animals were higher than those for the controls, although some fairly large variations between animals prevented the difference from reaching significance at the 29th week.

Variations in numbers and proportions of the rumen ciliates were no greater than would be expected from previous work (Boyne, Eadie \& Raitt, 1957; Kurihara et al. I 668 ). However, animal variability even under the controlled conditions of the present experiment has been demonstrated again in the development and establishment of 
Ophryoscolex (Eadie, I967) and, to a less marked degree, of Diploplastron affine. This illustrates the need for replication and control in experiments when rumen ciliate populations are being studied. We were unable to find any other features common only to the animals in which Ophryoscolex had developed.

Flagellate protozoa have been regularly seen to develop in the rumen by $7 \mathrm{~d}$ of age or less in ciliate-free lambs and calves spatially isolated from other animals but kept in a building containing, or recently vacated by, adult ruminants. In the present study the building used had previously housed pigs and no adult ruminants were within aerial contact. The flagellates did not develop until $5-7$ weeks later than normal in the ciliate-free lambs and it appeared that they originated from the inoculum given to the faunated group. This suggests that, although rumen flagellates are transmitted without direct contact between animals (Eadie, I962), it is necessary for the establishment of these organisms that the host be kept in a building in which adult ruminants are or have recently been housed.

The role of a rumen ciliate population must always be considered in relation to the ration and animal management being used. We cannot infer, for example, that no difference would have been found if the dietary intake had been close to the $\mathrm{N}$ maintenance level. If a high-starch diet had been used other differences might have become apparent. The only justified conclusion is that in the present study such changes as were caused either directly or indirectly by the presence of the ciliate population clearly were not large enough to be reflected in animal performance.

We wish to thank the following for their co-operation and assistance at different stages of the experiment: Dr K. L. Blaxter, Miss Ann Bostock, Dr Margaret I. Chalmers, Mr A. C. Dalgarno, Dr J. Davidson, Mr G. C. Hunter, Dr A. S. Jones, Mr I. McDonald, Mr S. O. Mann, Dr E. R. Ørskov, Mr R. S. Reid, Mr F. W. Wainman and Dr F. G. Whitelaw. We also thank Mr W. Shand for his competent technical assistance.

\section{REFERENCES}

Abou Akkada, A. R. \& El Shazly, K. (1964). Appl. Microbiol. 12, 384.

Abou Akkada, A. R. \& El Shazly, K. (1965). F. agric. Sci., Camb. 64, 25 I.

Association of Official Agricultural Chemists (1960). Methods of Analysis 9th ed. Washington: Association of Official Agricultural Chemists.

Becker, E. R. (1932). Q. Rev. Biol. 7, 282.

Becker, E. R. \& Everett, R. C. (1930). Am. F. Hyg. II, 362.

Becker, E. R., Schulz, J. A. \& Emmerson, M. A. (1930). Iowa St. F. Sci. 4, 215.

Boyne, A. W., Eadie, J. M. \& Raitt, K. (I957). F. gen. Microbiol. 17, 414.

Brouwer, E. (1965). Publs Eur. Ass. Anim. Prod. no. I I, p. $44 \mathrm{I}$.

Chalmers, M. I., Cuthbertson, D. P. \& Synge, R. L. M. (1954). F. agric. Sci., Camb. 44, 254.

Chalmers, M. I., Davidson, J., Eadie, J. M. \& Gill, J. C. (r968). Proc. Nutr. Soc. 27, 29 A.

Christiansen, W. C., Kawashima, R. \& Burroughs, W. (1965). F. Anim. Sci. 24, 730.

Dubois, M., Gilles, K. A., Hamilton, J. K., Rebers, P. A. \& Smith, F. (1956). Analyt. Chem. $28,350$.

Eadie, J. M. (1962). \%. gen. Microbiol. 29, 563.

Eadie, J. M. (1967). F. gen. Microbiol. 49, 175 .

Eadie, J. M., Hyldgaard-Jensen, J., Mann, S. O., Reid, R. S. \& Whitelaw, F. G. (I 970). Br. F. Nutr. 24, 157.

Fell, B. F., Kay, M., Whitelaw, F. G. \& Boyne, R. (1968). Res. vet. Sci. 9, $45^{8}$.

Heilmeyer, L. (1943). Spectrophotometry in Medicine p. 7o. London: Hilger. 
Hobson, P. N., Mann, S. O. \& Summers, R. (x966). F. gen Microbiol. 45, 5 P.

Hugget, A. St. G. \& Nixon, D. A. (1957). Lancet ii, p. 368.

Hungate, R. E. (1 966). The Rumen and its Microbes p. 126. London: Academic Press Inc. (London) Ltd. Klopfenstein, T. J., Purser, D. B. \& Tyznik, W. J. (I966). J. Anim. Sci. 25, 765.

Kurihara, Y., Eadie, J. M., Hobson, P. N. \& Mann, S. O. (Ig68). F. gen. Microbiol. 51, 267.

Luther, R., Trenkle, A. \& Burroughs, W. (1966). F. Anim. Sci. 25, I 1 I6.

Pounden, W. D. \& Hibbs, J. W. (I950). 7. Dairy Sci. 33, 639.

Storry, J. E. \& Millard, D. (1965). F. Sci. Fd Agric. 16, 4 I 7 .

Wainman, F. W. \& Blaxter, K. L. (1969). Publs Eur. Ass. Anim. Prod. no. 12, p. 429. 